\title{
IDEOLOGISK
}

\section{FORLØPER FOR}
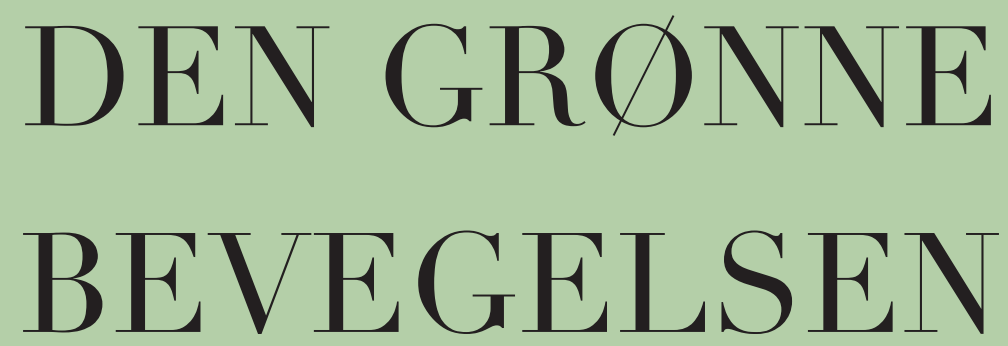

En tankesmie assosiert med Mir Hossein Musavi skisserte rammen for «muslimsk levemodus» i forkant av 2009-valget i Iran. Hva var dens visjon for den islamske republikken?

\section{Av Kjetil Selvik, forsker ved Fafo og førsteamenuensis II ved Institutt for kulturstudier- og orientalske språk, Universitetet i Oslo}




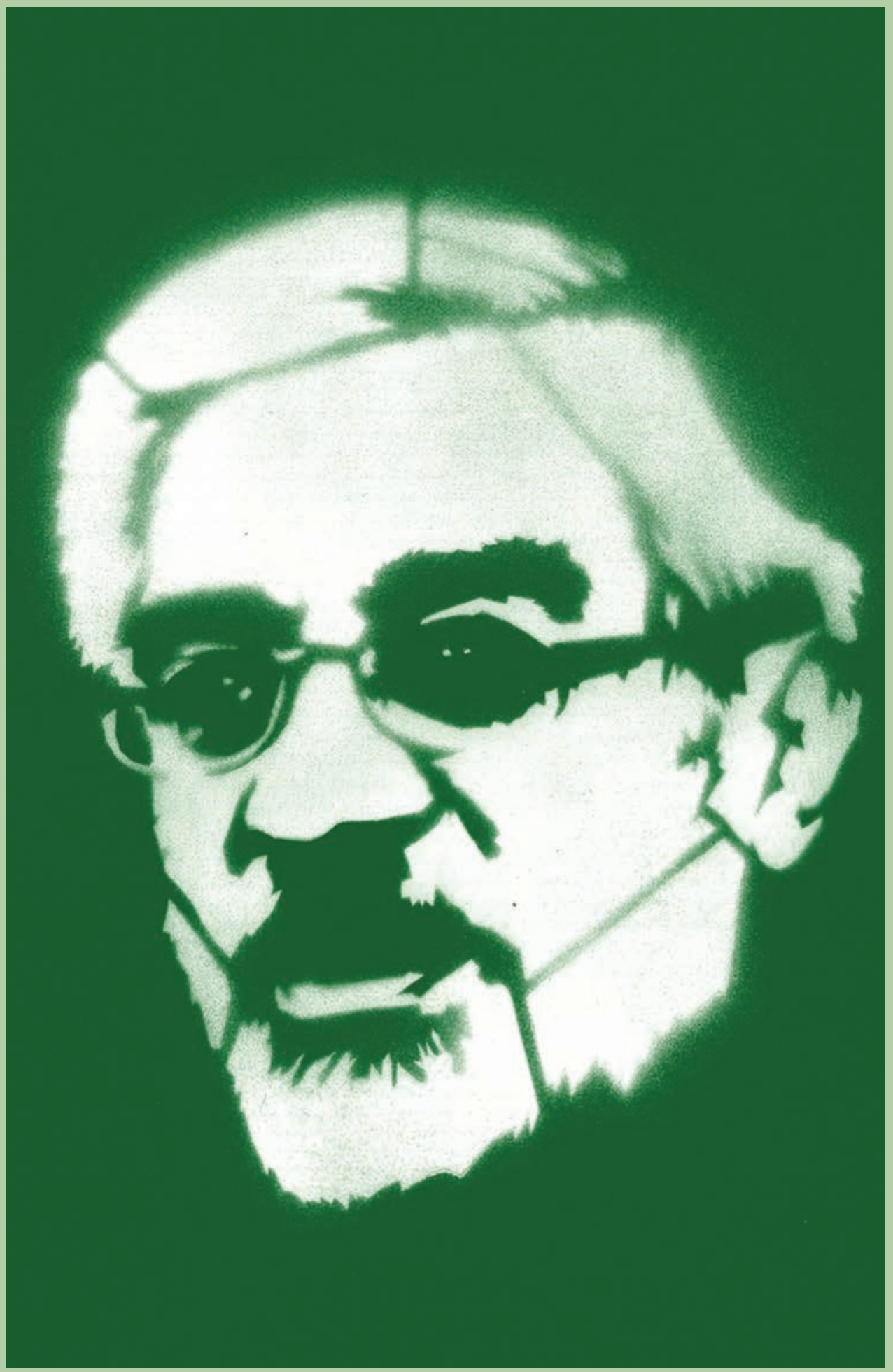


DEN GRøNNE BEVEGELSEN (Jonbesh-e sabz) som oppsto etter presidentvalget i juni 2009 er den største folkelige protestbevegelsen i den islamske republikkens historie. Den reagerte på kåringen av Mahmud Ahmadinejad som valgets vinner og mobiliserte under parolen «Hvor er min stemme?« (Rai-e man kojast?). Ifølge bevegelsen var Mir Hossein Musavi, som hadde brukt grønt som sin valgkampfarge, valgets egentlige vinner. Striden om valgresultatet førte til store og vedvarende folkelige demonstrasjoner, sivil ulydighet og omfattende politisk undertrykkelse.

Mir Hossein Musavi var Den grønne bevegelsens symbol og fremste lederskikkelse. Gjennom I8 uttalelser som ble offentliggjort $\mathrm{i}$ tiden etter valget formulerte han en krass kritikk av myndighetene og krevde respekt for befolkningens politiske og sivile rettigheter. Han tok således steget fra regimets rekker, med åtte år som statsminister bak seg og godkjenning fra Vokterrådet, til å bli leder for en sosial og politisk bevegelse. I februar 20II ble han satt i husarrest sammen med sin hustru Zahra Rahnavard.

At Musavi skulle ende opp som undertrykket leder for en bred folkelig protestbevegelse var vanskelig å forutsi da han i mars 2009 presenterte sitt kandidatur til det forestående presidentvalget. Han var ikke regnet som den tydeligste reformkandidaten og mange politiske observatører reagerte faktisk med skuffelse da tidligere president Mohammad Khatami, som opprinnelig hadde lansert sitt kandidatur, trakk seg til fordel for Musavi. Når Khatami var ute, anså mange Mehdi Karrubi som den mest liberale reformkandidaten.

Musavi presenterte seg nemlig som presidentkandidat fra et tilsynelatende konservativt ståsted. Han tilegnet seg begrepet osulgar, direkte oversatt «en som forholder seg til røttene», som Ahmadinejad og hans antireformbevegelse gjorde bruk av i betydningen nykon-

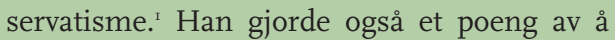
henvende seg til tradisjonelle, konservative valgbastioner som befolkningen i det fattige Sør-Teheran og de frivillige sikkerhetsstyrkene Basij. Budskapet var dog et annet enn Ahmadinejads populisme og Musavi la ikke skjul på at han ønsket reform. Han introduserte uttrykket osulgar-e eslahtalab, «en reformist som forholder seg til røttene», for å beskrive sin linje. Reformen skulle komme innenfra, ved å vende tilbake til den islamske republikkens opprinnelige prinsipper.

$\odot \odot \odot$

At Mir Husein Musavi skulle ende opp som undertrykket leder for en protest-

bevegelse var vanskelig å forutsi.

$\odot \odot \odot$

Musavi var ute etter å vinne oppslutning om sin plattform blant de konservative i systemet. Han holdt armlengdes avstand til det ledende reformistpartiet Mosharekat og politikere som etter de konservatives syn hadde vendt ryggen til den islamske republikken. ${ }^{2}$ Musavis velkjente anseelse hos revolusjonsfaderen Khomeini, uklanderlige politiske rulleblad og konsensusorienterte tilnærming vant ham faktisk støtte i de konservatives rekker. ${ }^{3}$ Støtten gjorde det vanskeligere for regimet å marginalisere og fryse ham ut da han anklaget Ahmadinejad for valgfusk.

Etter valget tok Musavi av seg silkehanskene og forlot sin forsiktige tilnærming. Det ble også klarere for omverdenen hva han hadde ment med «republikkens opprinnelige prinsipper». Kjernepunktet for Musavi var at den 
islamske republikken utgikk av folket. Han beskrev revolusjonen som en genuint folkelig bevegelse og grunnloven av 1979 som byggestein for en demokratisk orden. Han krevde umiddelbar retur til dette fundamentet for den islamske staten.

Musavis ideologiske plattform var ikke av det lettvinte slaget. Uttalelsene under den akutte politiske krisen sommeren og høsten 2009 bar preg av å være nøye giennomtenkt. Litteraturen om Den grønne bevegelsen gir imidlertid få holdepunkter om hvor Musavi hentet inspirasjon til uttalelsene sine fra. Vi kjenner rammen; at han historisk tilhørte det islamske venstre og ble formet av revolusjonsideologen Ali Shariati, i likhet med de fleste andre som senere skulle inngå i reformbevegelsen. ${ }^{4}$ Men den mer umiddelbare foranledningen, fra årene da Musavi var ute av politikken, har ikke vært gjenstand for engelskeller skandinaviskspråklige analyser. Formålet med denne artikkelen er å kaste lys over én viktig kilde til Musavis politiske tankesett.

\section{Foreningen for enhet og samarbeid (FFES)}

Seks måneder før presidentvalget i 2009 ble jeg introdusert for Ali-Reza Beheshti i Teheran. Ali-Reza Beheshti er forlegger, professor ved Tarbiyat Modarres-universitetet, og sønn av Ayatollah Beheshti, en av de mest sentrale figurene i den islamske revolusjonens historie. ${ }^{5}$ Kontoret hans vender ut mot 7. tir-plassen, som fikk sitt navn etter dagen ayatollah Beheshti ble drept i bombeangrepet mot Det islamske republikanske partiet $\mathrm{i}$ I98I. ${ }^{6}$ Beheshti fortalte meg at han var aktiv i en gruppe som kalte seg Foreningen for enhet og samarbeid (Jamiipat-e touhid va ta'avun), som hadde jobbet med et strategidokument de siste fem årene. Dokumentet bar tittelen «Muslimsk levemodus» (Olgu-үe zist-e mosal-

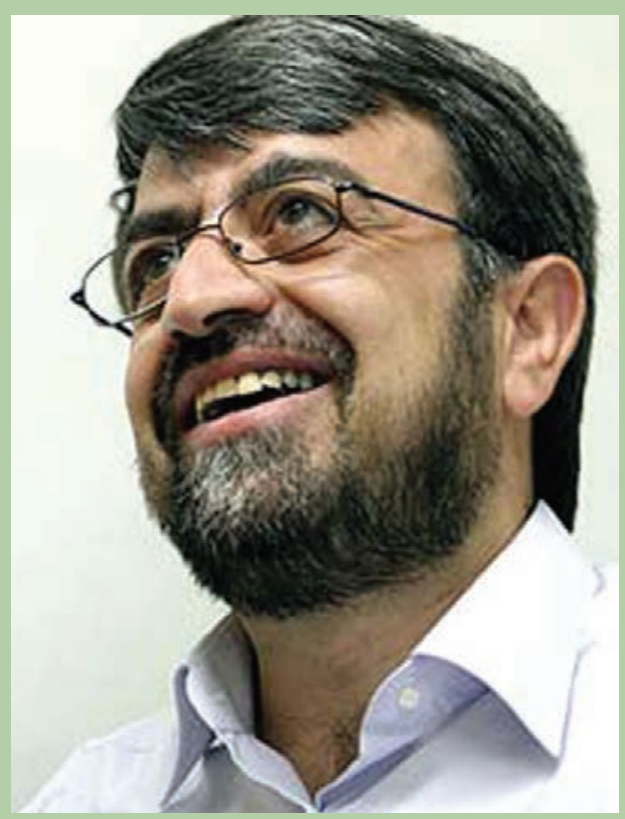

Ali-Reza Beheshti, medlem av Foreningen for enhet og samarbeid.

mani) og var ifølge Beheshti et forsøk på “å se forbi hverdagslige politiske problemer og konflikter i Iran og kaste et nytt blikk på det islamske systemet".?

I iranskspråklig Wikipedia omtales FFES som en "reformorientert politisk gruppe" som jobbet for å overtale Mir Hossein Musavi til å stille som presidentkandidat i 2009 -valget. ${ }^{8}$ Gruppen ble formelt presentert i januar 2009 da den avholdt sitt første offentlige møte $i$ nærvær av nettopp Mousavi, Mohammad Khatami og Khomeinis barnebarn Hassan Khomeini. ${ }^{9}$ Foreningens generalsekretær var Ali-Reza Beheshti. Foruten ham besto sentralkomiteen av åtte personer med en blanding av akademisk og politisk fartstid. ${ }^{10}$

Initiativtakerne til FFES var misfornøyd med funksjonsmåten til politiske partier og forståelsen av politikk i Iran. Beheshti beklaget at partier ofte sprang ut av personlige nettverk på innsiden av statsapparatet istedenfor å starte med en filosofi, et program, eller en 
tanke. Han trakk frem Kargozaran, Mosharekat og Rah-e Khosh-e Khedmat som eksempler. Førstnevnte kunne i Beheshtis øyne best beskrives som en «klubb» av og for politikere som kjente hverandre fra Rafsanjanis regjering, mens Mosharekat oppsto rundt personen og regjeringen Khatami. Da Ahmadinejad kom til makten dannet han partiet Rah-e Khosh-e Khedmat som bar preg av å være hans valgkampgruppe. "Vi trenger partier som former staten (doulat-saz) og ikke bare er statens produkter (sakht-e doulat)" konkluderte Beheshti."

Når det gjaldt forståelsen av politikk, mente han å se en tendens til at iranske polit-

\section{$\odot \odot \odot$}

Det er et forsøk på å definere en $n y$ plattform for utøvelse av politikk innen rammen av den islamske republikken.

\section{$\odot \odot \odot$}

ikere bare tror de kan påvirke når de sitter med makten: "De ser ikke på innflytelse som en kontinuerlig prosess som for eksempel De Grønne i Storbritannia, som prøver å påvirke politikk og diskurser uavhengig av om de er i posisjon eller ikke. Vi har ikke slike bevegelser i dette landet", sukket Beheshti. ${ }^{\text {12 }}$

FFES var til giengjeld et forsøk på å skape nettopp dette. Foreningen fremsto som en tankesmie som hadde tatt mål av seg å endre fundamentet for iransk politikk. "Utgangspunktet vårt er at det ikke finnes en logisk sammenheng mellom de islamske og republikanske delene av det politiske systemet", forklarte Beheshti, "vi ønsker å skissere en modell for hvordan iranere kan leve med hverandre og med den iranske staten". ${ }^{13}$ Modellen ble presentert under åpningskonferansen i januar 2009 og i dokumentet «Muslimsk levemodus». I forkant hadde FFES sendt dokumentet til ledende personligheter i den islamske republikken, inkludert lederen, Ali Khamenei, med ønske om kommentarer. På grunn av uroen rundt 2009-valget stoppet imidlertid prosessen opp og dokumentet ble liggende i skuffen. Den følgende fremstillingen er basert på den upubliserte versjonen jeg fikk overlevert av Beheshti. ${ }^{14}$

Før vi fordyper oss $\mathrm{i}$ «Muslimsk levemodus» kan det imidlertid være nyttig å plassere FFES i forhold til temaet islamsk nytenkning som iranske religiøse intellektuelle er kjent for. Selv om tankesmien legger til grunn en liberal tolkning av islam og med stor sannsynlighet er påvirket av verkene til muslimske nytenkere som Abdolkarim Sorush, ${ }^{15}$ Mohammad Mojtahed Shabestari ${ }^{16}$ og Mohsen Kadivar, ${ }^{17}$ står vi her overfor et langt mer avgrenset prosjekt av praktisk-politisk natur. «Muslimsk levemodus» er ingen teologisk avhandling eller filosofisk betraktning som tilbakeviser allmenne oppfatninger om tilværelsen og religionen. Det dreier seg om et pragmatisk forsøk på å definere en ny plattform for utøvelse av politikk innen rammen av den islamske republikken. FFES er opptatt av å skape forbindelser med massene og bringe folket tilbake i politikken.

\section{Foreningens syn på den islamske republikken} I sin II. uttalelse etter presidentvalget i 2009 beskriver Mir Hossein Musavi den islamske republikken som "resultatet av vårt folks hundreårige kamp og manifesteringen av deres streben for frihet, uavhengighet, rettferdighet og fremskritt i skyggen av fromhet".$^{18}$ Likheten er påfallende til dokumentet «Muslimsk levemodus», hvor ansatsen lyder som følger: ${ }^{19}$ 
"Irans islamske revolusjon er forlengelsen av bevegelsene og forsøkene på å vinne frihet og bekjempe undertrykkelse $i$ dette land og folks historie. Strid mot utbytting, kolonialisme og despoti, monoteisme, frihetslengsel, uavhengighetsønske, rettferdighetskamp, alle elementene som ga kraft til iransk liv og identitet [...] manifesterte seg $i$ den islamske revolusjonen". ${ }^{20}$

Den islamske revolusjonen var ifølge forfatterne den største og desidert mest innflytelsesrike sosiale bevegelse det moderne Iran har sett. Den maktet å forene kulturelle tradisjoner (islam og iranskhet) med politisk fornying (republikanisme) i en frigjøringsorientert politisk diskurs med svar på spørsmål i den virkelige verden. Syntesen mellom religion og frihet ble nedtegnet i Grunnloven som igjen ble vedtatt i folkeavstemming. Grunnloven har ifølge FFES behov for justering og forbedring, "som ethvert produkt av menneskelig erfaring", men omtales like fullt som en dyrebar arv fra den islamske revolusjonen". ${ }^{21}$

Styrken i den islamske republikkens tidlige fase lå for FFES i organisk kontakt mellom folket og systemet. Når vanlige mennesker inntok maktsentra og politiske institusjoner tok de med seg "lojalitet til revolusjonen, interesse for muslimske spørsmål, forsvar for iransk identitet, kollektiv hukommelse og lærdom fra historiske begivenheter" som tilførte staten ressurser. Med tiden har imidlertid islam og republikanisme glidd fra hverandre og systemet mistet sin folkelige forankring. Dermed har den islamske republikken mistet sin dynamikk og makter ikke som før å skape praktiske løsninger.

FFES peker ikke ut syndebukker for den negative utviklingen, og går ikke i historiske detaljer. Den sporer årsaken til gapet mellom stat og samfunn til en mangel på rotfesting, teoretisk og institusjonelt, av målene for den islamske revolusjonen. Målene var uttrykt i slagordene om rettferdighet, frihet, uavhengighet og fremskritt. Slagordene uttrykte essensen i folkets krav og brukes fortsatt flittig av alle politiske fraksjoner. De er imidlertid utilstrekkelig reflektert i systemets ideologi og lovverk, ifølge tankesmien. ${ }^{21}$

«Muslimsk levemodus» inviterer til å tenke nytt rundt den islamske republikkens grunnprinsipper. Som fra Musavi, lyder oppfordringen om at disse prinsippene må utdypes og settes ut i praksis. Innfallsvinkelen skiller seg fra standard liberal kritikk som tar utgangspunkt i en vestlig demokratisk modell, den liberale rettsstat, og sammenlikner realiteten i Iran med denne. Fra et liberalt perspektiv vil mange hevde at det fantes iboende demokratiske svakheter i det islamske politiske systemet fra starten. FFES' påstand er tvert imot at noe var fundamentalt riktig i den islamske revolusjonen. Den brede, spontane og vedvarende mobiliseringen uttrykte nemlig folkets vilje. Både Musavi og FFES vil finne tilbake til denne essensen (mahiyat) i det iranske politiske prosjektet.

Dertil hører at islam anses som en integrert del av veien fremover. "Noen har overflatisk sluttet fra den spirituelle krisen at islam må ut av styre og stell” påpeker «Muslimsk levemodus». "Vi skal imidlertid argumentere for at islam, som den siste monoteistiske religion, utgjør den mest komplette veiledning for sosialt arbeid." ${ }^{23}$ Hele dokumentet fra tittel til fotnoter - er svøpt i islamske termer og symboler. ${ }^{24}$ Motsatt glimrer direkte referanser til vestlig litteratur med sitt fravær. ${ }^{25}$

Det kan være flere årsaker til dette valget. Det må imidlertid sees i sammenheng med tenketankens uttalte ambisjon om å legge til 
rette for en ny diskurs som kan forene alle politiske krefter i den islamske republikken. ${ }^{26}$ I et system hvor spørsmålet om vestlig innflytelse er politisert kan referanser til vestlige forfattere skape barrierer mot mange av de konservative. Særlig fordi reformistene i utgangspunktet anklages for å være femtekolonister, eller i beste fall nyttige idioter, for Vesten. Ved å rotfeste et demokratisk, politisk rammeverk i referanser som er gjennomført islamsk og iransk, sender FFES et signal om at demokrati ikke må forveksles med vestlig import. Også Musavi er opptatt av at grunnlaget for demokratisk styresett kan utledes fra lokale drivkrefter, prinsipper og verdier.

\section{Grunnleggende betraktninger}

Når «Muslimsk levemodus» presenterer sine aksiomer er dermed utgangspunktet og de aller fleste kildehenvisningene Koranen. I sine tanker om eksistens (ontologien) slår dokumentet fast at bestanddelene i tilværelsen er komplementære, i interaksjon, og avhengige av hverandre. De utgiør et system som stadig er i utvikling, men hvis grunnleggende regler er fastlagte. ${ }^{27}$ Om menneskets natur og vesen sier teksten at den grunnleggende refleksen er å prøve å nærme seg Gud. Dette tar form av streben etter Guds grunnleggende egenskaper; godhet, barmhjertighet og rettferdighet. Egenskapen som fremfor alt kjennetegner mennesket er evnen til å foreta valg. Hun eller han har evne til å skjelne rett fra galt, ondt fra godt, og lære av sine erfaringer. Overfor Skaperen, naturen og andre har mennesket både rettigheter og plikter. ${ }^{28}$

Under erkjennelsesteori (epistemologi) understreker dokumentet at mennesket aldri kan nå den absolutte innsikt og sannhet, som er forbeholdt Gud. Ikke desto mindre er mennesket et bevisst vesen, i kraft av sine

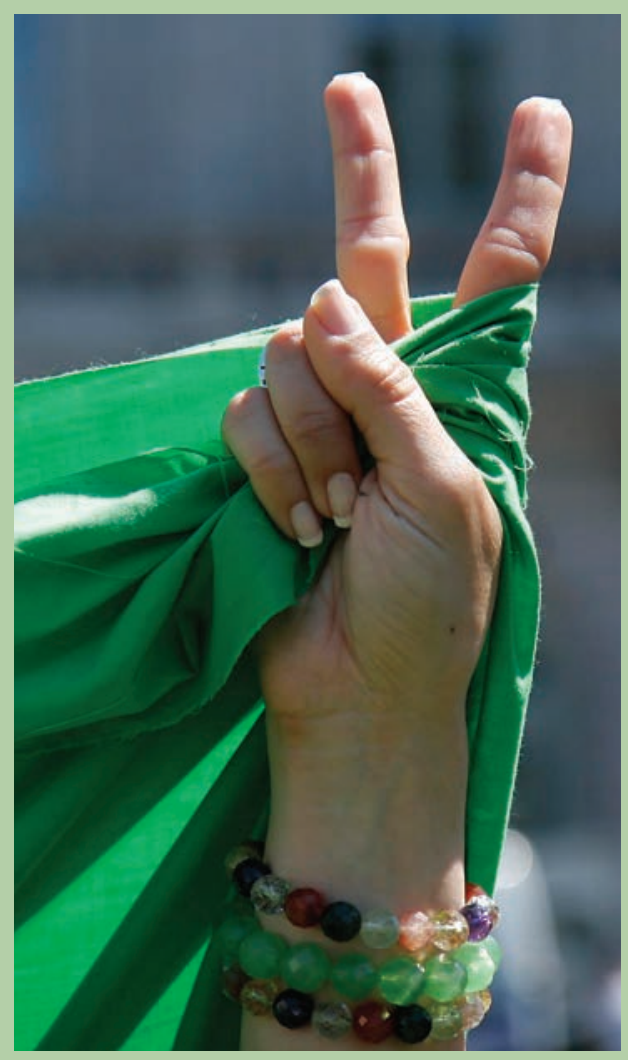

En demonstrant fra Den grønne bevegelsen gjør v-tegnet.

sanser, erfaringer, tanker og inspirasjoner, med evne til å erverve kunnskap. ${ }^{29}$

Disse koranfunderte betraktningene om menneskets natur, evnen til å lære og deretter ta valg er sentrale for FFES. De leder frem mot det som skal bli et bærende element i «Muslimsk levemodus»; argumentet om at stat og samfunn bør baseres på en konsensussøkende offentlig argumentasjon. Før resonnementet bringes dit har imidlertid teksten noen grunnleggende observasjoner om religionens rolle. Mennesket søker, ifølge «Muslimsk levemodus», av natur etter et narrativ som kan gi livet mening. Det trenger tankemessige rettesnorer for sin livsførsel og hjelp til å velge det gode og skyve bort det onde..$^{30}$ Religioner verden over har som funk- 
sjon å tilby svar på menneskets spørsmål om tilværelsen og det hinsidige. Profetene har blitt sendt av Gud for å veilede menneskeheten mot lykke og frelse. ${ }^{31}$ Islam er takket være «profetenes segl», profeten Muhammad, den mest komplette veileder for hvordan mennesket skal leve. Islam kaller de troende til "respekt for alle menneskers verdighet, respekt for andre menneskers liv, dialog for felles forståelse og grunnleggende prinsipper, og samarbeid for fredelig sameksistens." ${ }^{32}$

I dette trossystemet er meningen med livet å oppfylle potensialet til å nærme seg Guds kjærlighet, bevissthet og perfeksjon. Samtidig er kamp mot all undertrykking, urettferdighet, vold og tvang, overgrep mot menneskets verdighet og trusler mot menneskets tankeog valgprosesser, "del av muslimens absolutte plikter." ${ }^{33}$

For å realisere idealene eller normene i et verdisystem trenger man ifølge «Muslimsk levemodus» en rasjonell prosess for å iverksette konkrete og praktiske tiltak. En må gjøre rede for premissene, resonnere logisk, bestemme kriteriene for rett og galt, og dernest vurdere utfallet. ${ }^{34}$ Slik lyder oppskriften på det FFES kaller en konsensussøkende offentlig argumentasjon (aqlaniyat-e jami-ye touhidi). Hensikten med denne offentlige meningsbrytingen er å luke ut svakheter i politikkens fundamenter og sørge for at beslutninger tas på best mulig grunnlag. Slik kan den islamske republikken gjenvinne sin styrke og vitalitet, og gienforene de grunnleggende elementene islam og folkemeningen. ${ }^{35}$

Beheshti forklarte meg at tanken om konsensussøkende offentlig argumentasjon var basert på den amerikanske filosofen John Rawls' idé om rettferdighet som rimelighet. ${ }^{6}{ }^{6}$ Når det gjelder offentlige anliggender, argumenterer Rawls, er en nødt til å ta hensyn til hva andre mennesker finner akseptabelt og søke kompromisser. ${ }^{37}$ «Muslimsk levemodus» nevner imidlertid ikke Rawls' tenkning eksplisitt. Isteden presiserer den at den offentlige argumentasjonen er touhidi, konsensussøkende, eller direkte oversatt «monoteistisk», i betydning av «å ikke stride mot religiøse eller rasjonelle prinsipper».$^{3^{8}}$ Beheshti forklarte

$$
\odot \odot \odot
$$

Individets og fellesskapets rettigheter må utledes av samfunnets grunnleggende trossystemer, verdier og overbevisning.

$$
\odot \odot \odot
$$

også at tankesmien så tegn til konsensussøkende offentlig argumentasjon i den første islamske staten i Medina. ${ }^{39}$

Tankesmien anbefaler konsensussøkende offentlig argumentasjon for "å klargjøre folket og sivilsamfunnets rettigheter og plikter, [og styrke] sikkerhet, rettferdighet, frihet, nasjonal identitet og uavhengighet, samt andre kilder til forandring og fremskritt"..$^{\circ}$ Individets og fellesskapets rettigheter og plikter må utledes av samfunnets grunnleggende trossystemer, verdier og overbevisning, og nedfelles i lover gjennom offentlig argumentasjon. ${ }^{41}$ For at dette skal kunne finne sted er det en annen forutsetning som må være til stede. En må anerkjenne behovet for «velmenende sosial kritikk» (naqd-e ejtima'i-ye moshaffaqane) som redskap og plikt. Sosial kritikk er ikke en øvelse som skal forbeholdes intellektuelle, men hviler som formaning på alle som tror..$^{42}$ Med henvisning til Koranens befaling om å "påby det gode og forby det onde" (al-'amr bi-l ma'ruf wa al-nahi 'an al-munkar) kaller FFES "kvinne og mann, gammel og ung, fattig og rik og alle etniske grupper" til å engasjere seg i det offentlige ordskiftet. 
Koransitatet om å påby det gode og forby det onde er en gienganger i islamistisk litteratur, der det brukes som teologisk bevis for at islam er en religion som ikke kan reduseres til en privatsak, men krever at de troende implementerer religiøs lov i samfunnet som helhet. Det er med andre ord en grunnpilar i den allmenne forestillingen om "islamsk stat" og legitimerer ofte en sterkt uliberal praksis, som for eksempel religiøs patruljering i Saudi-Arabia. «Muslimsk levemodus» understreker også viktigheten av å påby det gode og forby det onde: "Bare samfunn som overholder dette påbudet kan nå nye høyder, overvinne små og store kriser [...] fjerne de urene fra styre og stell og erstatte dem med personer som fortjener offentlige posisjoner" ${ }^{43}$ Ved å tolke det aktuelle koranverset som en oppfordring til å utøve sosial kritikk har samtidig tankesmien gitt det religiøse påbudet en original og gjennomført demokratisk vri. Det slås fast at gjennomføring av denne delen av islam krever ytringsfrihet. ${ }^{44}$ Det offentlige ordskiftet skal baseres på opplysthet og frihet.45 Og kapittelet konkluderer: "I et muslimsk levemodus basert på konsensussøkende offentlig argumentasjon skal alle stemmer høres." ${ }^{36}$

\section{Politiske utfordringer}

Etter å ha redegiort for de bærende prinsipper $i$ en muslimsk levemodus vender FFES blikket mot uavklarte spørsmål og utfordringer det er avgjørende for den islamske republikken å håndtere. Åtte temaer trekkes frem som særlig grunnleggende: forholdet mellom tradisjon og fornying; å være borger og den sivile sfære; makten og staten; individet og fellesskapet; pluralisme og sameksistens; overbærenhet og moderasjon; sikkerhet; og levebrød, velferdstjenester og velstand. Mens brorparten av fotnotene i det foregående henviste til

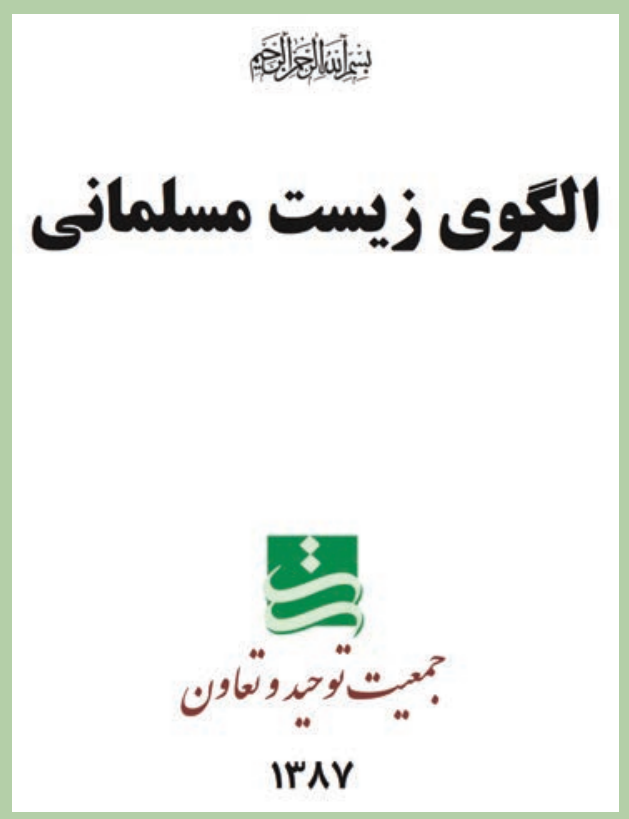

Forsiden til «Muslimsk levemodus».

Koranen er referansepunktet i denne delen av dokumentet Irans grunnlov av I979. Dette er også et trekk en finner igjen i Musavis uttalelser etter 2009-valget.

Skulle en oppsummere Musavis uttalelser og «Muslimsk levemodus» i én setning, kunne en kanskje si som følger: Det dreier seg om en demokratisk lesning av revolusjonen og grunnloven som vil ikke-demokratiske politiske praksiser i den islamske republikken til livs. Som tankesmien avslutningsvis slår fast i soleklare ordelag: "I et republikansk styringssystem kan ikke lederne hente sin politiske makt i kilder som unnslipper folkets overvåkning, og lederne har sin legitimitet i kraft av å tilfredsstille folkets krav." ${ }^{47}$

Sitatet leder tankene hen mot doktrinen om «den rettslærdes styre», velayat-e faqih, som brukes til å legitimere Ali Khameneis opphøyde posisjon i det politiske systemet. Ifølge mange konservative har lederen sin autoritet fra Gud og trenger ikke ta hensyn til 


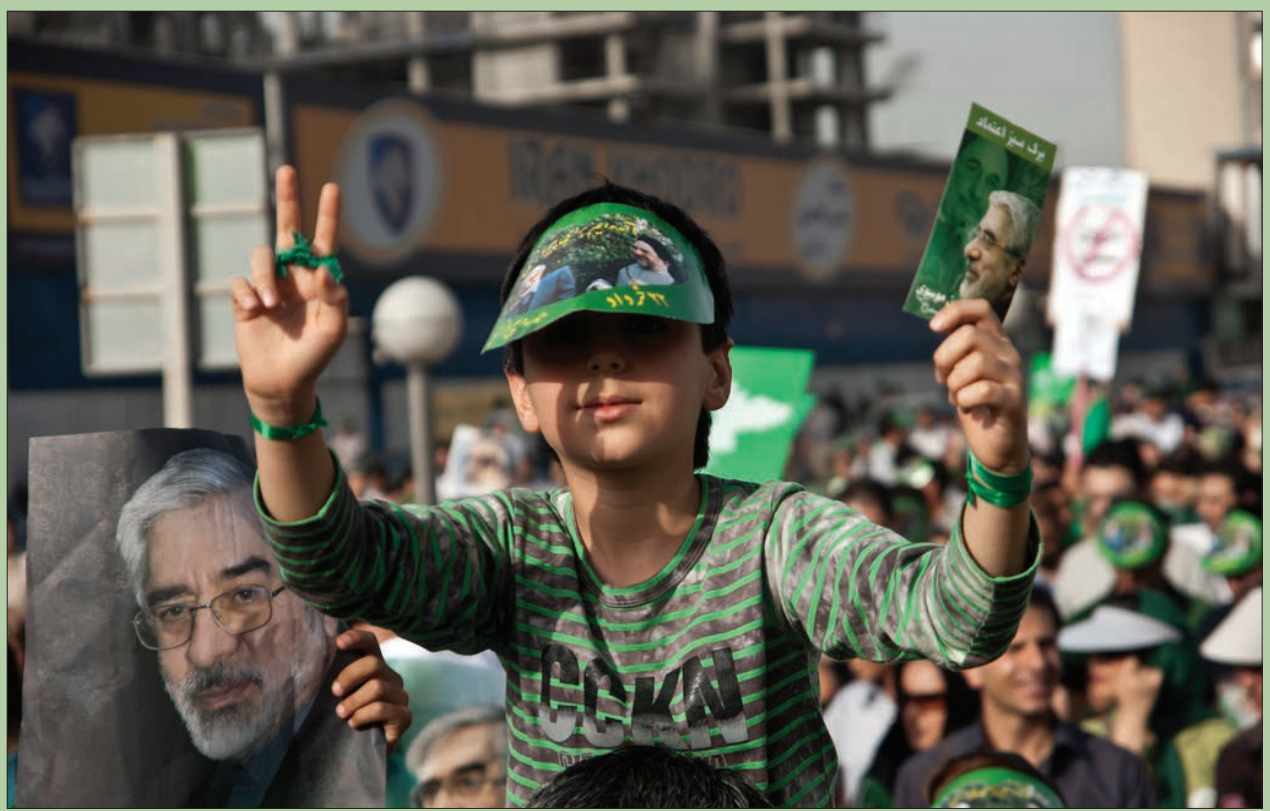

Mir Husein Musawis støttespillere - Den grønne bevegelsen - protesterte i Irans gater sommeren og høsten 2009.

folkemeningen. Dette avvises kontant i sitatet over. Det er dog påfallende at «Muslimsk levemodus» aldri omtaler begrepet velayat-e faqih. Dokumentet har verken tilløp til teologisk diskusjon av doktrinen eller direkte omtale av fenomenet som mer enn noe preger iransk politikk i dag. Begrunnelsen synes å være taktisk. Iranske politiske krefter har siden revolusjonen vært splittet mellom tilhengere og motstandere av velayat-e faqih, og siden fremveksten av reformbevegelsen mellom dem som forstår konseptet demokratisk og autoritært. $\AA$ nevne velayat-e faqih er å bringe frem disse skillelinjene. Fremgangsmåten FFES ville forsøke var å skape enighet om demokratiske grunnprinsipper på tvers av slike skiller. Derfor er de politiske utfordringene som trekkes frem i «Muslimsk levemodus» generelle.

Omfanget av denne artikkelen gir ikke plass til å gå i dybden på de åtte ovennevnte temaene, men jeg vil kort oppsummere hovedtrekkene. Med tanke på tradisjon og for- nying (sonnat va tajaddod) er dokumentet opptatt av å finne en balanse som sikrer en dynamisk utvikling uten å avskjære folket fra sin identitet. "Fornying i Iran har ofte kommet i form av import" beklager dokumentet, ${ }^{4}$ og respekt for tradisjonen blitt misforstått som blind imitasjon. Den islamske republikkens forening av islam og republikanisme representerer et unikt alternativ til begge.

Om muligheten for å være borger (shahrvandi) sier «Muslimsk levemodus» at den avhenger av både politiske og juridiske forhold. Den avhenger også av kulturelle, sosiale og økonomiske forutsetninger som gjør individet i stand til å identifisere- og velge den rette vei. ${ }^{49}$ Borgerne trenger derfor politiske rettigheter som må nedfelles i lovverket, men også et helhetlig system som kan styrke deres personlige kompetanse. I fravær av et velfungerende sivilsamfunn i Iran er staten (i det minste foreløpig) nødt til å bidra til dette.

På temaet makten og staten (qodrat va 
doulat) er dokumentets anliggende å fortelle iranerne at det finnes en annen og mer positiv forståelse av makt enn den persondominerte og undertrykkende versjonen de vanligvis legger til grunn. Makt utøvd gjennom staten kan være fellesskapets redskap for å nå de målene det har satt seg. Forutsetningen, presiserer «Muslimsk levemodus», er å basere det politiske fellesskapet på en konsensussøkende offentlig argumentasjon. ${ }^{5 \circ}$

En konsensussøkende offentlig argumentasjon vil også bidra til å avdempe spenningsforholdet mellom individet og fellesskapet (fard va jam'), når individet føler at det har tatt del i fellesskapets beslutning. I tillegg er påbudet om å legge til rette for sosial kritikk en sperre mot alle former for flertallsdiktatur og overkjøring av individet. ${ }^{5 t}$

Om pluralisme og sameksistens (gunaguni va hamzisti) er dokumentets utgangspunkt at det i samfunnet finnes mange ulike diskurser, kulturelle identiteter (etniske og religiøse) og modeller for det lykkelige liv. Det at mennesker tar valg, og dermed ulike valg, er som forklart nedenfor grunnleggende kjennetegn for vår art. Et av de viktigste målene for et islamsk samfunn er å legge til rette for at menneskene kan leve ut denne egenskapen..$^{52}$ Samtidig giør en konsensussøkende offentlig argumentasjon en dialog med «den andre» mulig, og den skaper rom for en felles plattform. Kun slik kan det oppstå ekte enhet i mangfoldet. ${ }^{33}$

Om behovet for overbærenhet og moderasjon (modara va tasahol) sier «Muslimsk levemodus» at muslimske samfunn har en utfordring i å regulere frihetens grenser fordi de sjeldent har levd under annet enn despoti. En hovedmålsetting i en muslimsk levemodus er som tidligere forklart å skaffe mest mulig rom for samfunnet og individets utfoldelse, men da må borgerne samtidig få opplæring i overbærenhet og moderasjon. Hensikten med dette er ikke å legge noen bånd på den helt grunnleggende verdien frihet. Snarere handler det om å vise respekt for den andres rett til å velge sin tro og overbevisning. ${ }^{54}$

Når det gjelder sikkerhet (amniyat) beklager dokumentet at "noen makter og stater" misbruker dette temaet for å legitimere sin politiske kontroll. Den rådende sikkerhetsdiskursen bygger på trusler og frykt.55 Som alternativ til dette foreslår FFES en annen forståelse av sikkerhet som kalles "menneskelig sikkerhet" (amniyat-e ensani), og minner om FN-konseptet human security..$^{56} \AA$ sørge for denne formen for sikkerhet, poengterer «Muslimsk levemodus», er den mest grunnleggende prioriteten i en islamsk stat og samfunn. Uten å legge til rette for at innbyggerne kan utfolde sine tanker og utnytte sine talenter er det ikke mulig å oppnå fremskritt og lykke.57

I forlengelsen av dette understreker dokumentet behovet for levebrød, velferdstjenester og velstand (ma'ishat, takaffol-e ejtema'i va refah): "Det er ikke mulig å løfte menneskesinnet uten at basisbehovene er dekket." ${ }^{18}$ Ansvaret for å sikre velstand og velferdstjenester tilfaller ifølge tankesmien både individet, sivilsamfunnet og staten. ${ }^{59}$

\section{Forankre revolusjonens mål}

Innenfor dette rammeverket samler FFES trådene ved å utdype slagordene for den islamske revolusjonen: Rettferdighet, frihet, uavhengighet og islamsk republikk. Som tidligere nevnt mener tankesmien at alle politiske krefter deler disse målene, men at slagordene mangler forankring og plass i den islamske republikkens ideologi og lovverk.

Essensen i rettferdighet er, ifølge dokumentet, like muligheter for hvert menneske å utnytte sitt potensial. Et rettferdig styre legger 
forholdene til rette for at enkeltindividet kan foreta opplyste og frie valg, og realisere sin forståelse av fremskritt og lykke. Det gir ikke spesielle fordeler til opportunister (som i det nåværende systemet), men sørger for et system hvor makten er fordelt etter evner og prestasjoner (meritokrati) og som tar høyde for at mennesker har ulike evner og ressurser. ${ }^{60}$

Frihet handler om frihet fra alle former for overgrep, men må også legges til rette for $\mathrm{i}$ positiv forstand som muligheten til å leve ut

\section{$\odot \odot \odot$}

Referansene er islam, Koranen og grunnloven av 1979, likevel en reelt demokratisk visjon for republikken.

$\odot \odot \odot$

sin vilje. Det er en forutsetning for at mennesket skal kunne realisere sin iboende evne til å velge. Frihet er som sådan ifølge FFES en av islams mest grunnleggende verdier. «Muslimsk levemodus» nevner spesielt behovet for tros- og ytringsfrihet, trykkefrihet, forsamlingsfrihet og frihet til å bruke minoritetsspråk..$^{61}$

Uavhengighet, basert på iransk identitet, handler om fellesskapets frihet til å foreta egne valg. Kombinasjonen av å være muslim og iraner fikk i den islamske revolusjonen status som «nasjonalidentitet». Nasjonale identiteter er imidlertid ikke statiske størrelser og utvikler seg i takt med innbyggernes kultur og verdensanskuelse. Ved å styrke det kulturelle, sosiale og vitenskapelige fundamentet for iranernes identitet kan den islamske republikken stå støtt i møte med globalisering. ${ }^{62}$

Sist, men ikke minst, er islamsk republikk basert på en skrevet sosial kontrakt, den iranske grunnloven, og skal være et redskap for å realisere fellesskapets interesser. Dens suverenitet hviler i folket, som vil utnytte potensialet i stat og makt til å gjennomføre sine felles prosjekter. Tankesmien oppsummerer sitt budskap som følger:

"Den islamske republikken som politisk system er et svar på nødvendigheter; for det første muligheten for at alle medlemmene av samfunnet kan delta $i$ prosessen med å stake ut kursen $i$ harmoni med fellesskapets interesser [...]; for det andre garantien for at borgerne fritt og opplyst kan ta del $i$ landets administrasjon. Systemets bruk av islam som normgivende rammeverk skjer også gjennom folkets deltakelse. Betydningen av islamsk republikk er med andre ord å realisere islam gjennom konsensussøkende offentlig argumentasjon". ${ }^{63}$

\section{Konklusjon}

Tankegodset til FFES har ikke vært internasjonalt kjent, men fremstår som en viktig inspirasjonskilde for Mir Hossein Musavi. Det målbærer flere av temaene vi kjenner fra Musavis uttalelser etter 2009-valget. Blant disse er den voksende avstanden mellom folket og det politiske systemet, betoningen av grunnloven som rammeverk for en demokratisk sosial kontrakt, og behovet for å vende tilbake til revolusjonen og den islamske republikkens opprinnelige prinsipper. Både FFES og Musavi presenterer et rammeverk for reform innenfra som ikke ser behov for å vise til vestlige demokratiske idealer og kilder. Referansene er islam, Koranen og grunnloven av I979. Samtidig er det ingen tvil om at det er en reelt demokratisk visjon for den islamske republikken de forsvarer.

I kraft av sin innflytelse på Musavis diskurs kan FFES sies å være en ideologisk forløper for Den grønne bevegelsen. Tankesmiens opp- 
fordring om å skape forbindelser med massene og bringe folket tilbake til politikken er interessant når vi vet hva som skjedde i Iran i juni 2009. «Muslimsk levemodus» har åpenbart brodd mot makthaverne og den rådende politiske praksis i Iran, selv om det aldri nevnes navn og dokumentet er svøpt i religiøse og konsensusorienterte vendinger. Det minner om utviklingen til Musavi, som før valget konsentrerte seg om å skape støtte for sin reformagenda blant konservative i statssystemet. Etter valget ble han mer eksplisitt i sin kritikk og inntok rollen som leder for en sosial og politisk protestbevegelse. Den grunnleggende ideologiske forståelsen endret seg imidlertid ikke.

Etter 2009-valget har den politiske undertrykkelsen av Den grønne bevegelsen generelt, og Musavis støttespillere spesielt, undergravd eksistensgrunnlaget for FFES. Flere medlemmer av tankesmien har blitt fengslet, og Qurban Behzadiyan-Nejad, som ledet Musavis valgkampkontor, sitter fremdeles innelåst. Tankene som ble formulert i «Muslimsk levemodus» er til giengjeld vanskeligere å kontrollere. De har hatt sin effekt på Den grønne bevegelsen og påvirker trolig også deler av de konservative aktørene på innsiden av det politiske systemet.

\section{$\cdot f \cdot$}

I Uttrykket oversettes tidvis som «principalist» på engelsk.

2 Musavi avviste for eksempel høflig et tilbud fra den frittalende og profilerte reformisten Mustafa Tajzadeh om å organisere hans valgkampanje.

3 Under valgkampen ble det opprettet et konservativt valgkampkontor til Musavis støtte. Blant tilhengerne var Hamid Reza Katuzian, Hojjat-ol eslam Sayyed Reza Akrami, Ali Motahhari og Said Abutalib. http://www.bibaknews.com/fa/news/45899/\%D8 \%B3\%D8\%AA\%D8\%A7\%D8\%AF\%D8\%A7\%D8\%B5\%D9\%88\%D9\%84\%DA\%AF \%D8\%Br\%D8\%A7\%D9\%8A\%D8\%A7\%D9\%86-
\%D8\%AD\%D8\%A7\%D9\%85\%D9\%8A\%D9\%85\%D9\%88\%D8\%B3\%D9\%88\%D9\%8A\%D8\%AA\%D8\%B5\%D9\%88\%DB\%8C\%D8\%BI

4 Muhammad Sahimi: "The Political Evolution of Mousavi”, i Nader Hashemi og Danny Postel (red.). The People Reloaded: The Green Movement and the Struggle for Iran's Future, Brooklyn, NY: Melville House, 20IO. s. 234-254.

5 Ayatollah Muhammad Hosseini Beheshti var en av Khomeinis nærmeste støttespillere, ble leder for det innflytelsesrike revolusjonsrådet, spilte en nøkkelrolle i utformingen av grunnloven, og var generalsekretær for Det islamske republikanske partiet og leder for rettsvesenet da han ble drept i ig8I.

6 7. tir i den iranske kalenderen tilsvarer 28 . juni.

7 Intervju med Ali-Reza Beheshti, 07.I2.2008.

8 http://fa.wikipedia.org/wiki/\%D8\%AC\%D9\% 85\%D8\%B9\%DB\%8C\%D8\%AA_\%D8\%AA\%D9 \%88\%D8\%AD\%DB\%8C\%D8\%AF_\%D9\%88_\% D8\%AA\%D8\%B9\%D8\%A7\%D9\%88\%D9\%86

9 http://www.khabaronline.ir/detail/2I37

IO De åtte var Qurban Behzadiyan-Nejad, Gholam-Reza Zarifiyan, Jamshid Ansari, Hamze Ghalibi, Mujtaba Amiri, Abbas Manuchehri, Muhammad-Reza Tajik og Muhammad Baqerian. Da Mir-Husayn Musavi erklærte sitt kandidatur i presidentvalgkampen ble Behzadiyan-Nejad leder for valgkampkontoret og de andre aktive støttespillere.

II Intevju med Ali-Reza Beheshti, op. cit.

I2 Ibid.

I3 Ibid.

I4 En elektronisk utgave av dokumentet kan lastes ned fra Den grønne bevegelsens internett-side Kalame, se static3.kaleme.com/ozm_vo2.pdf. Sidetallene som refereres i denne artikkelen stemmer ikke overens med utgaven som ligger på nettet, men er tilgjengelig hos forfatteren.

I5 Se Soroush, Abdolkarim Soroush: Qabs va bast-e teorik-e shariat [Religiøs kunnskapsevolusjon]. Teheran: Sarat, I995 eller Teheran: Abdolkarim: Reason, Freedom, and Democracy in Islam: Essential Writings of Abdolkarim Soroush. Oxford \& New York: Oxford University Press, 2000;

I6 Mohammad Mojtahed: Hermenautik-e ketab va sunnat [Hermenautisk lesning av Koranen og Tradisjonene]. Teheran: Tarh-e nu, I996; Shabestari, Mohammad Mojtahed: Iman va Azadi [Tro og frihet]. Teheran: Tarh-e Nou, I997; Shabestari, Mohammad Mojtahed: Naqdi bar qera'at-e rasmi az din [Kritikk av den offisielle lesning av religionen]. Teheran: Tarh-e nu, 2000; Shabestari.

I7 Kadivar, Mohsen: Pluralism-e dini [Religiøs pluralisme]. 
Tehran: Salam, 1999; Kadivar, Mohsen: Daghdaghehaye hokumat-e dini [Religiøse staters bekymringer]. Tehran: Nashr-e Nay, 2000; Kadivar, Moshen: Haqq-ol nas: Eslam va hoquq-e bashar [Folkets rettigheter: Islam og menneskerettigheter]. Teheran: Kavir, 2008.

I8 http://www.princeton.edu/irandataportal/ elections/pres/2009/candidates/mousavi/Mousavi _Statement_5.9.2009.pdf

I9 Alle henvisninger til, og sitater fra, «Muslimsk leve modus» $i$ artikkelen er forfatterens egne oversettelser.

20 "Del I: Evaluering av 30 år med islamsk republikk". «Muslimsk levemodus», op. cit. s. I.

2I Ibid. S. I8-I9.

22 Ibid. s. 8

23 "Del II: teoretiske fundamenter", «Muslimsk levemodus», s. 26.

24 Mest fremtredende er bruken av touhid som blant annet inngår i navnet på selve tenketanken. Doktrinen om Guds enhet (arab: tawhid) er en hjørnestein i islam som uttrykt i trosbekjennelsen. Det er også et begrep som refereres i islamistisk ideologi som «bevis» på at samfunnet ikke kan deles i religiøse og sekulære deler. Den venstreorienterte revolusjonsideologen Ali Shariati anvendte begrepet for å beskrive sitt ideal om «det klasseløse samfunn» (jame'e- $y e$ touhidi).

25 Dette til tross for at Beheshti under vårt møte holdt fram John Rawls som en av «Muslimsk levemodus» fremste inspirasjonskilder.

26 "Forord", Muslimsk levemodus, s. 2.

27 “Del II: Teoretiske fundamenter", «Muslimsk levemodus», s. 28.

28 Ibid. s. 29 .

29 Ibid. s. 30.

30 Ibid. s. 3I.

3I Ibid. s. 32.

32 "Del II: Teoretiske fundamenter", «Muslimsk levemodus», s. 32-33.

33 Ibid. s. 35 .

34 Ibid. s. 36.

35 Ibid. s. 38 .

36 Intevju med Ali-Reza Beheshti, op. cit.

37 Rawls, John: Rettferdighet som rimelighet. Oslo: Pax forlag, 2003.

38 “Del II: Teoretiske fundamenter”, «Muslimsk leve- modus», s. 37.

39 Intevju med Ali-Reza Beheshti, op. cit.

40 "Del II: Teoretiske fundamenter", Muslimsk levemodus, s. 38 .

4I Ibid. s. 39 .

42 Ibid. s. 42.

43 Ibid. s. 43.

44 Ibid. s. 43.

45 Ibid. s. 45.

46 Ibid. s. 45 .

47 Ibid. s. 82.

48 Ibid. s. 46.

49 Ibid. s. 48.

50 Ibid. s. 5I-52.

5 I Ibid. s. 55 .

52 Ibid. s. 57.

53 Ibid. s. 58.

54 Ibid. s. 59-6I.

55 Ibid. s. 62.

56 Uttrykket human security ble lansert av FN i I990årene for å balansere staters tradisjonelle vektlegging av national security og understreke at mennesket er den grunnleggende referansen for sikkerhet. Det slo fast at stater har plikter overfor sine innbyggere som er grunnlaget for deres suverenitet.

57 Ibid. s. 66.

58 Ibid. s. 68.

59 Ibid. s. 69.

60 Ibid. s. 69-74.

6I Ibid. s. 74-76.

62 Ibid. s. 76-79.

63 Ibid. s. 82. 